\title{
DISTURBANCES OF THE HOLOCENE LAKE-BOG SEDIMENT SUCCESSION AS REVEALED BY POLLEN RECORD FROM WIETRZYCHOWICE (SOUTHEASTERN KUJAWY, CENTRAL POLAND)
}

\author{
Eva Břízová ${ }^{1}$, Malgorzata Roman ${ }^{2}$ \\ ${ }^{1}$ Czech Geological Survey, Klárov 3/131, 11821 Prague 1, Czech Republic; eva.brizova@geology.cz \\ 2 Department of Geomorphology and Palaeogeography, Faculty of Geographical Sciences, University of Łódź, \\ Narutowicza 88,90-139 Łódź, Poland; mroman@geo.uni.lodz.pl
}

\begin{abstract}
Results of geological and pollen investigations of the lake-bog sediments from the section Wietrzychowice W5, located nearby the Neolithic Funnel Beaker Culture (FBC) megaliths, are presented. The pollen data reveal that sedimentation at Wietrzychowice has begun at the beginning of the Holocene (Preboreal). Pollen analysis was used to determine stratigraphy with regard to sediment characteristics. The pollen spectrum was divided into 8 LPAZes (1-7Xa, $7 \mathrm{Xb}$ ) which were also, where possible, stratigraphically classified. Radiocarbon dating of $6730 \pm 90 \mathrm{BP}(5730-5480$ $\mathrm{BC}, \mathrm{MKL}-702)$ at depth of $1.20 \mathrm{~m}$ confirmed the pollen analysis age estimation. Five settlement episodes were found in organic sediments in the upper part of the W5 core. The first was presumably during the Preboreal, the second in the early Atlantic, the third in the late Atlantic (probably Neolithic FBC), the fourth in the early Middle Ages and the last one in the late Middle Ages. The pollen analysis was useful to point irregularities in sediment succession. Such a situation made palaeoenvironmental interpretation difficult, but further research is still needed to enable an accurate reconstruction.
\end{abstract}

Key words: pollen analysis, geoarchaeology, post-depositional disturbances, human activity, Holocene, central Poland.

Manuscript received 17 June 2015, accepted 6 November 2015

\section{INTRODUCTION}

The vegetation is visually the most distinct component in the landscape and its composition is a result of both abiotic and biotic factors. Based on vegetation composition, deductions can be made concerning other factors, including climate, pedology, geomorphology and even a time of human colonisation of the region and a scope and quality of human activities. Pollen analysis is a basic method for reconstruction of the past vegetation development during the Pleistocene and Holocene.

Palynological investigations of biogenic deposits in archaeology are used to express man and environment interactions and to correlate phenomena derived from pollen analysis and archaeological investigations. Using floral indices of husbandry, phases of man`s extensive activity can be extrapolated. Considering the entirety of past vegetation, it is possible to determine environmental conditions, in which consecutive communities existed. Radiocarbon dating is of significant value in this respect.

The southeastern Kujawy region in central Poland has been intensively used for farming since early Neolithic due to its fertile soils (Jażdżewski, 1938; Grygiel and Bogucki 1997). A number of sites were documented in this area, in which artifacts of the Neolithic Funnel Beaker culture (FBC), i.e. ceramics, stone and flint tools as well as megalithic tombs, were found. The people producing such ceramics and constructing massive stone structures inhabited southeastern Kujawy between mid-IV and mid-III millennium BC. Huge megaliths nearby Wietrzychowice, the most magnificent of them reaching $115 \mathrm{~m}$ in length, were well recognized by Professor Konrad Jażdżewski in the 1930s and 1960s (Jażdżewski, 1938; Jadczykowa, 1970, 1971).

During the last few years geological (Roman, 2010) and notably archaeological investigations at Wietrzychowice have been taken up once again and revealed numerous remains of the FBC husbandry in several sites in the megaliths vicinity (Bř́zová et al., 2014). Noteworthy are three sites, which can be interpreted as settlements, 3 to 5 ha each. The largest of them was located at Osiecz Mały, ca $1 \mathrm{~km} \mathrm{NE}$ from the Wietrzychowice site (Fig. 1) where abundant material has been excavated, indicating long-term (several centuries) residency of the FBC community during the IV millennium 


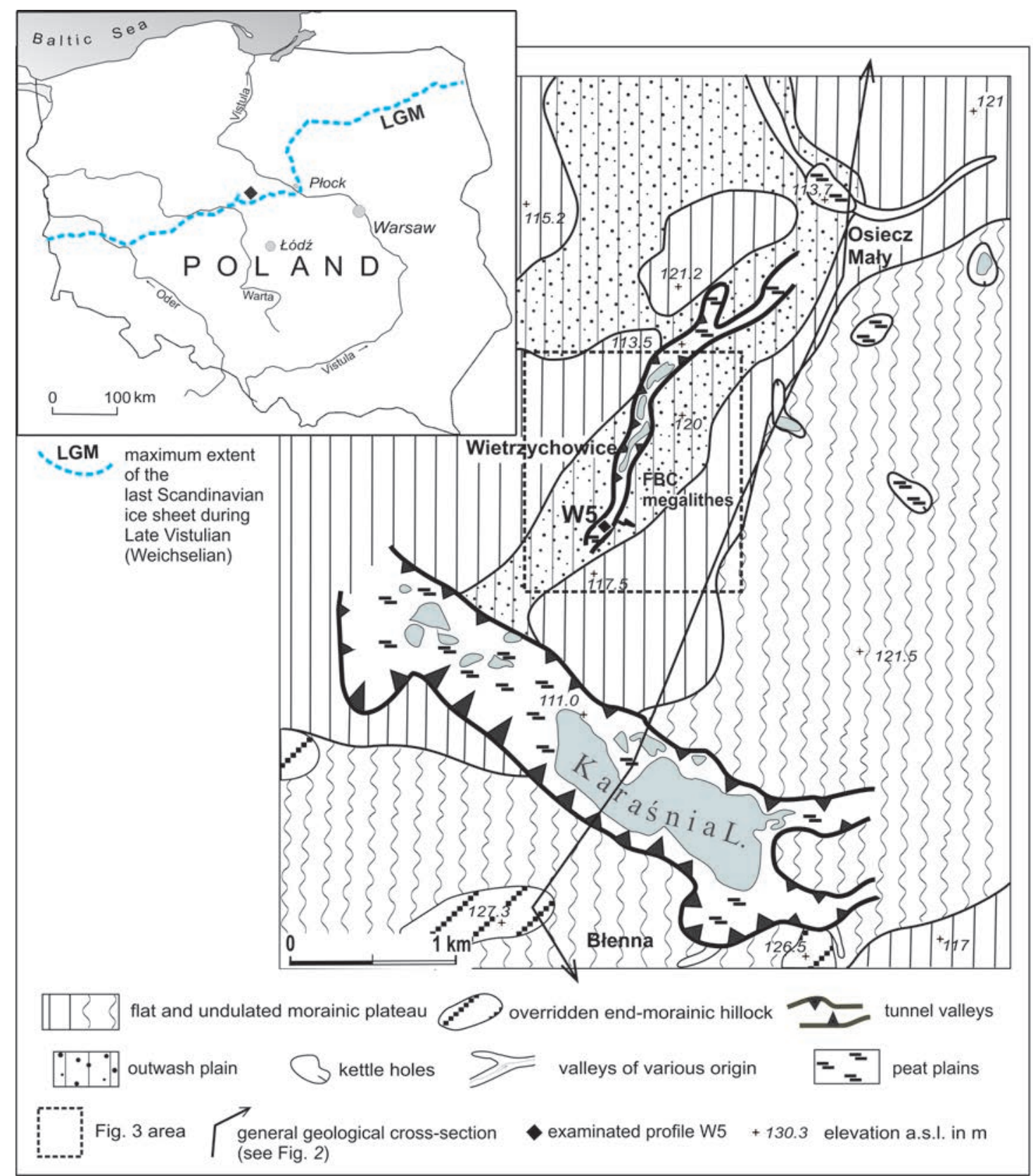

Fig. 1. Location of the Wietrzychowice site and geomorphological outline of its environs.

BC. Neolithic FBC settlements are spread at a morainic plain and also in nearby tunnel valleys, bottoms of which are featured by lakes, peat-bogs and slight tributaries. In contrast to abundant archaeologic findings evidence of human activities in pollen record at the Wietrzychowice vicinity remains open and the one presented in this paper, is the first.

The aim of the work was to present anthropogenic traces and climatic features in the Holocene lake-bog sediment succession, using plant indicators to trace activities of prehistoric people and also to point out how seemingly intact deposits, in macroscopic taxation, could be found disturbed as seen in results of palynological investigations.

\section{REGIONAL SETTING AND STUDY SITE}

The Wietrzychowice site is located in the southeastern part of the Kujawy Lakeland, within an area embraced by the Płock ice-lobe during the late Weichselian maximum (19-18 ka BP) related to the Poznań (Frankfurt) Phase (Roman, 2010, Fig. 1). An undulant morainic plateau at 115-123 m a.s.l. is the predominant landform in the area. It is composed mainly of till, locally covered by glaciofluvial sand with gravel, $0.5-1.5 \mathrm{~m}$ thick and increasing up to $4 \mathrm{~m}$ alongside the glacial tunnel valleys. The morainic plateau is cut by numerous tunnel valleys of various ranges with NW-SE and NE-SW orientations. Among the noticeable landforms, there are overridden end moraines near Boniewo and Błenna (Figs 1,2), marking pre-maximum short ice sheet standstills (Roman, 2010) and kettle holes, commonly filled with delluvial sands and boggy deposits.

At Wietrzychowice a small tunnel valley is found, ca $2 \mathrm{~km}$ long and 40-150 $\mathrm{m}$ wide, running NW-SE (Figs 1, 3). A nar- 
row lake $300 \mathrm{~m}$ long as well as peat plains and bogs form the present bottom of the valley. Within the peat plain tilted to the lake from the south and located in a close vicinity of the megaliths, 30 boreholes were done. A log with thickest biogenic deposit (section W5, Fig. 3) was chosen for palynological analysis (Table 1).

\section{METHODS}

Geological mapping was done in the area of $6 \mathrm{~km}^{2}$ around the Wietrzychowice FBC site and notably, the peat plain situated close to the megalith tombs and within the foot of a tunnel valley, was examined in detail. 30 boreholes fixed along 3 sections crosswise to the tunnel valley axis were done. Lacustrine and peat deposits from the core W5 (Fig. 3) were pollen analyzed (whereupon the lowermost part of a peat layer above lake deposits was radiocarbon dated. Radiocarbon analysis was performed and calibrated at the Cianowice Radiocarbon Laboratory in Poland. The age of $6730 \pm 90$ BP (5 730-5 480 cal yrs BC, MKL702 ) at the depth of $1.20 \mathrm{~m}$ was auspicious to take up consecutive tedious palynological examination.

31 samples were pollen analyzed (1 $\mathrm{cm}^{3}$ each). They were collected from the depth 2.05-0.30 m (Fig. 3) at every $5 \mathrm{~cm}$ and analyzed at every $5-10 \mathrm{~cm}$. Decomposition of inorganic component was carried out by HF maceration for ca 24 hours (Faegri and Iversen, 1964). An organic part, mainly cellulose, was removed by Erdtman's acetolysis (Erdtman, 1954). The sporomorphs were preserved in a mixture of ethyl alcohol, glycerine and distilled water.

Microscopic treatment included calculation of individual objects and was carried on the cover glass $22 \times$ $22 \mathrm{~mm}$. With a low frequency of pollen grains of woody plants, AP (an amount of AP above 100 was taken for statistical evaluation), only 1-10a preparations were done for individual samples. Raw counts of palynomorphs $(\mathrm{AP}+\mathrm{NAP}=100 \%)$ were the basis for a pollen diagram with a use of the POLPAL program (Walanus and Nalepka, 1999, 2010; Nalepka and Walanus, 2003). Among pollen grains and spores, a number of plant tissues

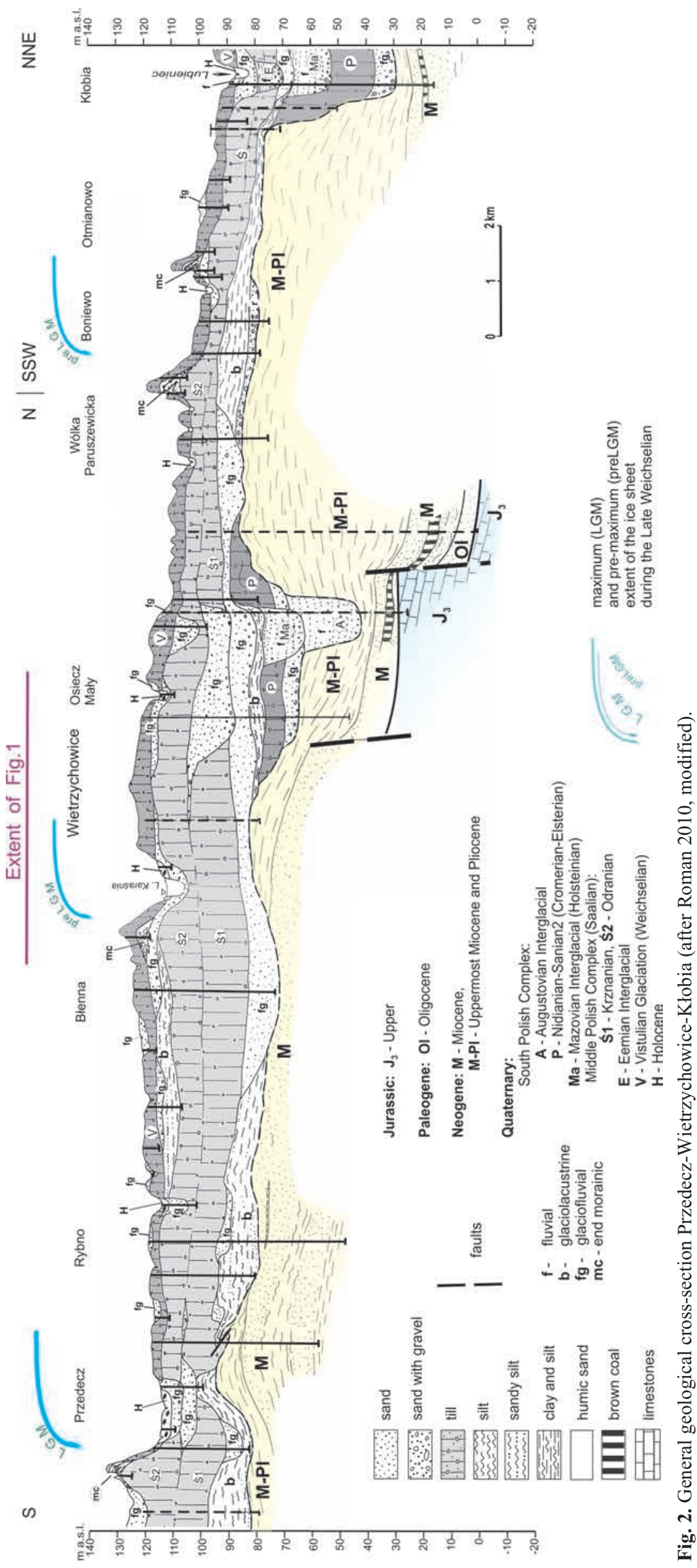




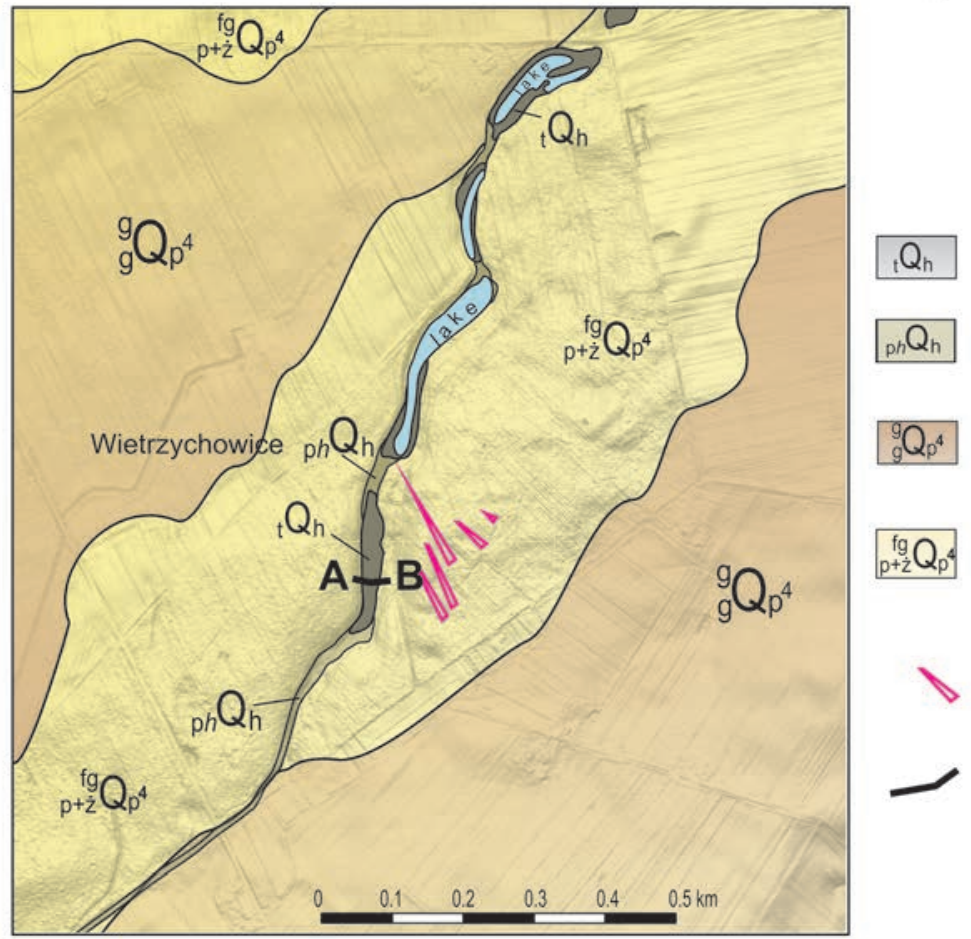

peat

(HOLOCENE)

humic sands

and mud

(HOLOCENE)

till

(PLEISTOCENE,

Vistulian Glaciation)

glaciofluvial sands

with gravel

(PLEISTOCENE

Vistulian Glaciation)

Funnel Baker Culture

megalithes

geological

cross-section A-B

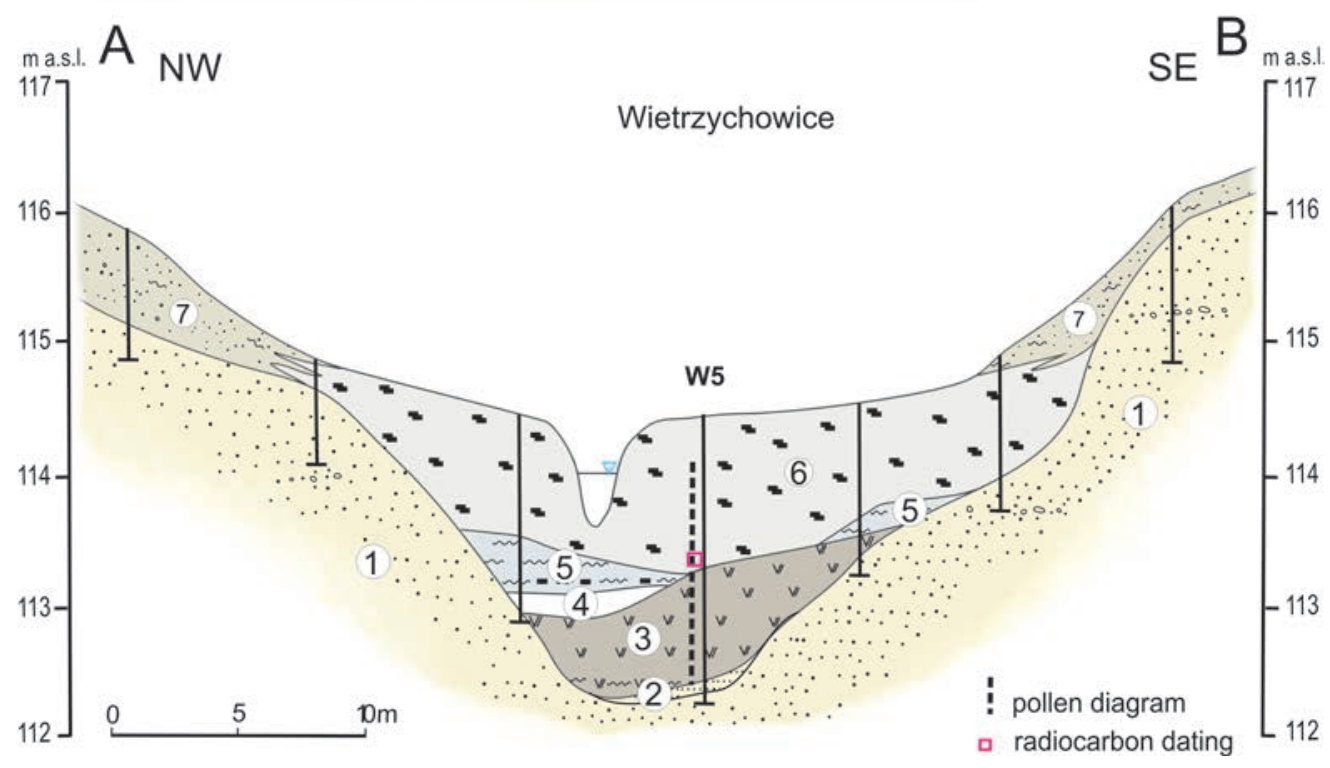

Fig. 3. Surface geology of the Wietrzychowice vicinity and geological cross-section A-B throughout a tunnel valley runs nearby Funnel Baker culture megaliths. Pleistocene: 1 - glaciofluvial sands and sands with gravel; Holocene: 2 - lacustrine fine sands with organic matter, 3 - gyttja, 4- lake chalk, 5- lacustrine silt and organic silt, 6-peat, 7 - deluvial sands and humic sands.

and microscopic animal remains were found during the microscopic analysis. Stratigraphy of the pollen succession was proposed and reconstruction of vegetation phases was produced using Firbas' (1949, 1952) division, modified by Mangerud (Mangerud et al., 1974; Walanus and Nalepka, 2010) (Table 2).

\section{RESULTS}

The main task of the carried out pollen analysis, besides the information about the vegetation, was a finding of natural sedimentary conditions and age determination. The pollen spectrum covers climatic-plant zones of the whole Holocene
(IV-X, Preboreal to late Subatlantic) and certain facts were discovered (Fig. 4) that will be described hereafter.

\section{Local pollen assemblage zones}

\section{PAZ WIE 1: Preboreal, depth 1.7-2.05 m, Pinus - Betula - Alnus - Salix}

The pollen spectrum corresponds most probably to the Preboreal (IV, 10 250-9 100 yrs BP). High frequency of AP pollen, mostly pine (Pinus) and birch (Betula), was found. More pollen grains of alder (Alnus), but less willow (Salix), were also present. Vitis-type and Viscum (semi-parasite most 
often on pine), Quercus, Ulmus, Tilia cordata, Picea, Picea and Carpinus represented a fairly thermophillic vegetation. In this phase, expansion of aqueous flora (Potamogeton, Lemna minor, Myriophyllum, Nuphar, Botryococcus, Cladocera) as well as of other wetland vegetation (Cyperaceae, Menyanthes trifoliata, Caltha-type, Sparganium/Typha angustifolia, Typha latifolia, Phragmitesn ) took place. A small lake was surrounded by alderwoods, willows and poplars. A green alga of the genus Botryococcus appeared together with mosses (Bryales) of the genus Sphagnum. Pinus cembra, Juniperus and Ephedra fragilis were characteristic pollen of the cold Late Glacial and the early Holocene climate and have been therefore enduring until the beginning of the Holocene. The cerealia T. Triticum (maybe redeposited) was a characteristic pollen of the late Holocene and is improbable in the Preboreal.

\section{PAZ WIE 2: Boreal, depth 1.5-1.7 m, Pinus - Betula - Salix - Corylus}

This part of the section belongs to the Boreal (V, 9100 - 7 $700 \mathrm{yrs}$ BP). In the pollen spectrum a larger content of pollen grains of pine (Pinus) and birch (Betula) appeared, with a continuous record of willow (Salix), poplar (Populus) and hazel (Corylus). In organic sediments the spores without the upper layer, which would have enabled a more precise determination, were common. They were classified into a morphological type of Polypodiaceae (Filicales monolete) and occurred together with spruce (Picea). There were some algae of the genera Botryococcus and Pediastrum, accompanied by a moss (Bryales) Sphagnum.

\section{PAZ WIE 3: early Atlantic, depth 1.2-1.5 m, Pinus - Quercetum mixtum (QM, Ulmus, Quercus, Tilia) - Cerealia}

This segment belongs to the early Atlantic (VI, 7 7006000 BP). The studied zone represented rather a small time stage covering a climatic optimum. The succession illustrated most an invasion of pine (Pinus) and alder (Alnus), less spruce (Picea), fir (Abies) and hornbeam (Carpinus). Cereals - Cerealia sp., Cerealia T. triticum and also a buckwheat (Fagopyrum) and other anthropogenic indicators (Artemisia, Centaurea cyanus, Chenopodiaceae, Brassicaceae, Apiaceae, Rumex, Asteraceae Liguliflorae, A. Tubuliflorae, Trifolium, Symphytum) characteristic for farming. The green algae were represented by the genus Botryococcus only. Quite a high content of pine pollen (Pinus) and radiocarbon dating $6730 \pm 90$ yrs BP (5 730-5 480 yrs BC, MKL-702) in the upper part of the section indicates the Atlantic age. Some pollen grains in the Czech Republic such as Fagopyrum, Centaurea cyanus indicated the Middle Ages. Pollen grains of synantrophic plants (Artemisia, Chenopodiaceae, Asteraceae Liguliflorae) and cereals (Cerealia sp., C. T. triticum) may appear in the Neolithic, but a buckwheat (Fagopyrum), found out in these sediments, was characteristic for the Middle Ages in the Czech Republic and was probably introduced by a man from its homeland in the Middle East (Bř́zová, 1998, 1999). In the territory of Poland pollen grains of Centaurea cyanus were found in the Atlantic sediments (see Nalepka, 2005; Ralska-Jasiewiczowa et al., 2004).
Table 1

Lithology of the examined log Wietrzychowice W5

\begin{tabular}{|c|c|c|}
\hline Depth $(\mathrm{m})$ & Sediments & Sedimentary environment \\
\hline $0.00-0.50$ & peat, slightly decayed, brown & boggy \\
\hline $0.50-1.23$ & moss-sedge peat, brown & boggy \\
\hline $1.23-2.05$ & $\begin{array}{c}\text { gyttja with calcareous } \\
\text { coarse-detritus, dark grey }\end{array}$ & lacustrine \\
\hline $2.05-2.10$ & $\begin{array}{c}\text { fine sand with organic matter, } \\
\text { laminated, blue-grey }\end{array}$ & lacustrine \\
\hline $2.10-2.30$ & sands, various grain size & glaciofluvial \\
\hline
\end{tabular}

Table 2

Stratigraphy of the Holocene

\begin{tabular}{|l|c|c|c|}
\hline HOLOCENE & $\begin{array}{c}\text { Modified stratig- } \\
\text { raphy by Bř́zová } \\
\text { (Dreslerová et al. } \\
\text { 2004), } \\
\text { uncal. yrs BP }\end{array}$ & $\begin{array}{c}\text { Modified } \\
\text { stratigraphy by } \\
\text { Mangerud } \\
\text { (Walanus and } \\
\text { Nalepka 2010), } \\
\text { conv. yrs BP }\end{array}$ & $\begin{array}{c}\text { Modified } \\
\text { stratigraphy by } \\
\text { Mangerud } \\
\text { (Walanus and } \\
\text { Nalepka 2010), } \\
\text { cal. yrs BC }\end{array}$ \\
\hline $\begin{array}{l}\text { SUBATLANTIC } \\
\text { IX, X }\end{array}$ & $2800-$ recent & $2500-$ recent & $600-$ recent \\
\hline $\begin{array}{l}\text { SUBBOREAL } \\
\text { VIII }\end{array}$ & $\begin{array}{c}5100 / 4500- \\
2300\end{array}$ & $5000-2500$ & $3800-600$ \\
\hline $\begin{array}{l}\text { ATLANTIC } \\
\text { VI, VII }\end{array}$ & $\begin{array}{c}7700-5100 / \\
4500\end{array}$ & $8000-5000$ & $7000-3800$ \\
\hline $\begin{array}{l}\text { BOREAL } \\
\text { V }\end{array}$ & $9100-7700$ & $9000-8000$ & $8200-7000$ \\
\hline $\begin{array}{l}\text { PREBOREAL } \\
\text { IV }\end{array}$ & $10250-9100$ & $10000-9000$ & $9500-8200$ \\
\hline
\end{tabular}

\section{PAZ WIE 4: late Atlantic, depth 1.2-0.8 m, Pinus - Quercetum mixtum - Cyperaceae-Poaceae}

The pollen spectrum corresponds to the late Atlantic (VII, $6000-5$ 100/4 500 BP). There is a high fraction of pollen grains of woody species (AP), primarily pine (Pinus). The individual pollen grains of herbs (NAP: Asteraceae Liguliflorae, Plantago major-media, Artemisia, Chenopodiaceae), cereals (Cerealia T. triticum) and Centaurea cyanus represent the farming, but not to a greater extent. A still dominating fraction is formed by wetland plants (Salix, Alnus, Populus, Cyperaceae, Sparganium/Typha angustifolia) and Polypodiaceae type. A high fraction of woody species (Pinus) is accompanied by a smaller amount of other AP (Betula, Tilia, Quercus, Ulmus, Populus) and also a small number of herbs (NAP). The shrub layer is relatively rich (Cornus sanguinea, Lonicera, Prunus-typ, Vitis). It is probable that there might have been Neolithic settlements.

\section{PAZ WIE 5: depth 0.8-0.7 m, Pinus - Picea - (Polypodiaceae)}

The pollen spectrum corresponds most probably to the Subboreal (VIII, 5 100-2 300 yrs BP). There is still a high frequency of woody species (AP), again mostly pine (Pinus), substantially less other woody species such as Picea, Betula, Alnus, Tilia, Quercus, Ulmus and Populus and there is also a small amount of herbs (NAP). In the sediments there are abundant ferns, represented by spores without perina (upper cover), which were classified as a morphological type of 
Polypodiaceae (Filicales monolete). Without the upper cover their more detailed determination is impossible.

\section{PAZ WIE 6: depth 0.7-0.55 m, Pinus - Betula - Alnus - Cyperaceae-aquatic plants}

A high fraction of alder (Alnus), which is characteristic for this place, alderwood and Cyperaceae predominate; moreover it is a period of expansion of aquatic flora (Potamogeton, Lemna minor, Myriophyllum, Utricularia, Botryococcus, Cladocera) and consequently marsh plants (Cyperaceae, Menyanthes trifoliata, Sparganium/Typha angustifolia, Typha latifolia). A mutual occurrence of juniper (Juniperus), stinging nettle (Urtica) and heather (Calluna vulgaris) may indicate human presence, which is characteristic for a pasture directly in a forest. Greater extension of these plants might have begun just due to a pasture. Cereals did not emerge any more. According to development of the plant cover, the sediment may be classified into the early Subatlantic (IX, 2800 yrs BP-500/700 AD).

\section{PAZ WIE 7: depth 0.55-0.3 m, Pinus - Salix - Alnus - Abies - aquatic plants - anthropophytes}

The pollen spectrum corresponds to the late Subatlantic of the early and late phase Xa (500-1 200 AD) and Xb (1 200 $\mathrm{AD}-$ recent). The examined part of the profile represented rather a small time stage covering the youngest part of the Holocene. In this period a pine (Pinus) was predominant, with small amounts of Betula, Quercus, Juniperus, Alnus, Picea and Abies. Herbs were represented sporadically by Cyperaceae, Sparganium/Typha angustifolia, Potamogeton, Lemna minor, Asteraceae Liguliflorae, A. Tubuliflorae, Chenopodiaceae, Artemisia and Centaurea cyanus. Upon the discovery of plant palynomorphs that accompanied a man (predominantly cereals), the period can be characterized as the Middle Ages without improved differentiation (early and late Middle Ages, Xa-Xb).

\section{DISCUSSION}

The pollen data confirm that the examined profile represents the Holocene, with the Preboreal (IV) at the beginning, via the following periods up to the late Subatlantic (X).

Soon afterwards, the human presence becomes visible but showing itself as questionable in the period of climatic optimum (VI, VII). In the Subboreal (VIII) man's traces did not occur, but they were noted only in the early (IX) and late Subatlantic (Xa, Xb). In the pollen diagram (Fig. 4) the human presence could not be reliably proved (improbable in the Preboreal) until the early and late Subatlantic (VI, VII, comparison Břizová and Bartošková, 1994; Břízová and Szwarczewski, 2005; Břizová, 2012a, b; Břízová et al., 2012).

During the Atlantic, if the locality or its surroundings was settled, the human presence was possible but vegetation that emerged here, was characterized by the types of the Middle Ages origin (Fagopyrum, Centaurea cyanus) in the Czech Republic. In the Kujawy Region pollen grains of Centaurea cyanus were found in the Atlantic sediments (Nalepka, 2005). Reliable findings of human activity did not become visible in the pollen diagram until early and late Mid- dle Ages in the upper part of the section at Wietrzychowice. There are five settlement phases in the pollen diagram, irrespective of reality. The first is only presumable in the Preboreal, the second in the early Atlantic, the third in the late Atlantic (probably Neolithic FBC), the fourth in the early Middle Ages and the last one in the late Middle Ages.

Deposition of organic material was initiated in the beginning of the Holocene during the Preboreal and possible redeposition is moreover exemplified by findings of Dinoflagellata cysts. The sediments at the botttom $(1.2-2 \mathrm{~m})$ and the sands below the organic part are classified as lacustrine, which is concurrently supported by pollen analysis (Fig. 4). Siltation and overgrowing of a small lake started at the beginning of the early Atlantic and corresponded to the largest warming during the Holocene and also the largest vegetation expansion (comparison e.g. Mentlík et al., 2010) and continued during the whole Holocene, being exemplified by abundant wetland vegetation (Potamogeton, Sparganium/Typha angustifolia, Cyperaceae, Lemna minor). Open water table probably endured during the deposition (e.g. Lemna minor, Potamogeton) but periodic flooding at higher precipitation and a more humid phase of the climate may have occurred.

\section{FINAL REMARKS}

Taking into account topography, geological setting and lithology of the W5 core from the Wietrzychowice site, it could be expected to find a continuous and undisturbed sediment record. Even radiocarbon dating and pollen analysis are not in contradiction. Merely the pollen spectrum, which directly indicated a human influence, is problematic. There are 5 traces of settlements (Fig. 4), found in organic sediments of the upper segment of the W5 core and referenced probably to the Preboreal, early Atlantic, late Atlantic (presumably Neolithic FBC), early Middle Ages and late Middle Ages. It is evident that the locality might have been frequently settled and therefore sedimentation was influenced by the humans. Furthermore, it is troublesome to assess reasons why deposits found to be of Atlantic age bear traces of Medieval human activity. Such disturbance most probably has been related to human and animal-inducted physical perturbations of the soft sediment surface, but no visible bed disturbances, insertions and structure changes in the peat section of the W5 core are noted.

A significance of the pollen record for our understanding of the Neolithic time, when farming groups of Funnel Beaker culture appeared in the Kujawy region, is obvious from a high proportion of published contributions from archaeologists (i.a. Czerniak, 1994; Rzepecki, 2004). In the presented case, a pollen analysis was useful to indicate irregularities in sediment succession, although such a situation makes palaeoenvironmental interpretation difficult and further research is needed to enable accurate reconstruction.

\section{Acknowledgements}

The authors thank Adam Myrta (Izbica Kujawska Community and Town Cultural Centre) for a financial support of the radiocarbon dating. 


\section{REFERENCES}

Břízová E. 1998. Pylová analýza sedimentu středověké Sněmovní ulice v Praze (Prague medieval Sněmovní street - pollen analysis of its sediments). Archaeologica Pragensis 14: 317-328.

Bř́zová E. 1999. late Glacial and Holocene development of the vegetation in the Labe (Elbe) River flood-plain (Central Bohemia, Czech Republic). Acta Palaeobotanica, Suppl. 2: 549-554.

Břizová E. 2012a. Historical influence of man on the vegetation record in the Prášilské Lake sediments (Bohemian Forest, Czech Republic). Folia Musei Rerum Naturalium Bohemiae Occidentalis, Geologica et Paleobiologica 46(1-2): 15-30.

Břízová E. 2012b. Reconstruction of vegetation and human impact from the sediments of the Rybárenská Sla mire (Bohemian Forest, Czech Republic). Silva Gabreta 18(2): 61-78. Vimperk.

Bř́zová E., Bartošková A. 1994. early medieval hillfort of Budeč: reconstruction of environment of the basis of pollen analysis. Sborník geologických věd, Antropozoikum 21: 75-86.

Bř́zová E., Kittel P., Papiernik P., Roman M., 2014. Warunki środowiskowe funkcjonowania osadnictwa pucharów lejkowatych (KPL) w Wietrzychowicach (SE Kujawy). In: Kittel P. et all. (ed.) Naturalne i archeologiczno-historyczne uwarunkowania osadnictwa średniowiecznego. VIII Sympozjum Archeologii Środowiskowej. WNG UŁ: 90-91.

Břízová E., Pazdur A., Piotrowska N. 2012. Upper Holocene development of vegetation and radiocarbon dating in the vicinity of the Cerhovka brook (Bohemian-Moravian Uplands, Czech Republic). Geochronometria 39(4): 251-262.

Bř́zová E., Szwarczewski P. 2005. Vliv člověka na lokální vývoj holocénní vegetace v nivě řeky Świder (Polsko) /Human impact in the development of the Holocene vegetation in floodplain/. Zprávy o geologických výzkumech v roce 2004: 57-59. Praha.

Czerniak L. 1994. Wczesny i środkowy okres neolitu na Kujawach $5400-3650$ p.n.e. ( early and Middle Period of the Neolithic in Kujavia 5400-3650 BC). Poznań, Instytut Archeologii i Etnologii Polskiej Akademii Nauk: 206 pp.

Dreslerová D., Břízová E., Růžičková E., Zeman A. 2004. Holocene environmental processes and alluvial archaeology in the middle Labe (Elbe) valley. In: Gojda, M. (Ed.) Ancient landscape, settlement dynamics and non-destructive archaeology. Academia, Praha: 121-171.

Erdtman G. 1954. An introduction to pollen analysis. Waltham (USA); 239 pp.

Faegri K. 1964. Textbook of pollen analysis. Copenhagen: 347 pp.

Faegri K., Iversen J. 1964. Textbook of pollen analysis. 347 pp. Scandinavian University Books, Copenhagen.

Firbas F. 1949, 1952. Spät- und nacheiszeitliche Waldgeschichte
Mitteleuropas nördlich der Alpen. I. Allgemeine Waldgeschichte. II. Waldgeschichte der einzelnen Landschaften. Jena (Fischer): 480 pp., 256 pp.

Grygiel R., Bogucki P., 1997. Early farmers in north-central Europe: 1989-1994 Excavations at Osłonki, Poland. Journal of Field Archaeology 24: 161-178.

Jadczykowa I., 1970. Sprawozdanie z badań prowadzonych w latach 1967 i 1968 w Wietrzychowicach, w pow. kolskim, na stanowisku 1. Prace i Materiały Muzeum Archeologicznym i Etnograficznym w Łodzi, Seria Archeologiczna 17: 125-143.

Jadczykowa I., 1971. Sprawozdanie z końcowego etapu prac badawczych na neolitycznym cmentarzysku grobowców kujawskich w Wietrzychowicach, pow. Koło. Prace i Materiały Muzeum Archeologicznym i Etnograficznym w Lodzi, Seria Archeologiczna 18: 93-103.

Jażdżewski K., 1938. Cmentarzyska kultury ceramiki wstęgowej i związane z nimi ślady osadnictwa w Brześciu Kujawskim. Wiadomości Archeologiczne 15: 1-105.

Mangerud J., Andersen, S.T., Berglund, B.E., Conner, J.J. 1974. Quaternary stratigraphy of Norden, a proposal for terminology and classification. Boreas 3(3): 109-128.

Mentlík P., Minár, J., Břízová, E., Tábořík, P., Stacke, V. 2010. Glaciation in the sourrounding of Prášilské Lake (Bohemian Forest, Czech Republic). Geomorphology 117:181-194.

Nalepka D. 2005. late Glacial and Holocene Palaeoecological Conditions and changes of vegetation cover under early farming activity in the South Kujawy Region (Central Poland). Acta Palaeobotanica, Suppl.6: 3-90.

Nalepka D., Walanus, A. 2003. Data processing in pollen analysis. Acta Palaeobotanica 43(1): 125.

Ralska-Jasiewiczowa M., Latałowa M., Wasylikowa K., Tobolski K., Madeyska E., Wright H.E. Jr, Turner Ch. (eds) 2004. late Glacial and Holocene history of vegetation in Poland based on isopollen maps. W. Szafer Institute of Botany, Polish Academy of Sciences, Kraków.

Roman M., 2010. Rekonstrukcja lobu płockiego w czasie ostatniego zlodowacenia (Reconstruction of the Płock ice lobe during the last glaciation). Acta Geographica Lodziensia 96: 1 171.

Rzepecki S., 2004. Społeczności środkowoneolitycznej kultury pucharów lejkowatych na Kujawach (Communities of the Middle Neolithic TRB Culture in Kujawy). Poznań: 235 pp.

Walanus A., Nalepka D. 1999. POLPAL. Program for counting pollen grains, diagrams plotting and numerical analysis. Acta Palaeobotanica, Suppl. 2: 549-554.

Walanus A., Nalepka D. 2010. Calibration of Mangerud's boundaries. Radiocarbon 52: 1639-1644. 
Wietrzychowice 5, Poland $52^{\circ} 24^{\prime} 45^{\prime \prime} \mathrm{N}$ $18^{\circ} 52^{\prime} 32^{\prime \prime} \mathrm{E}$

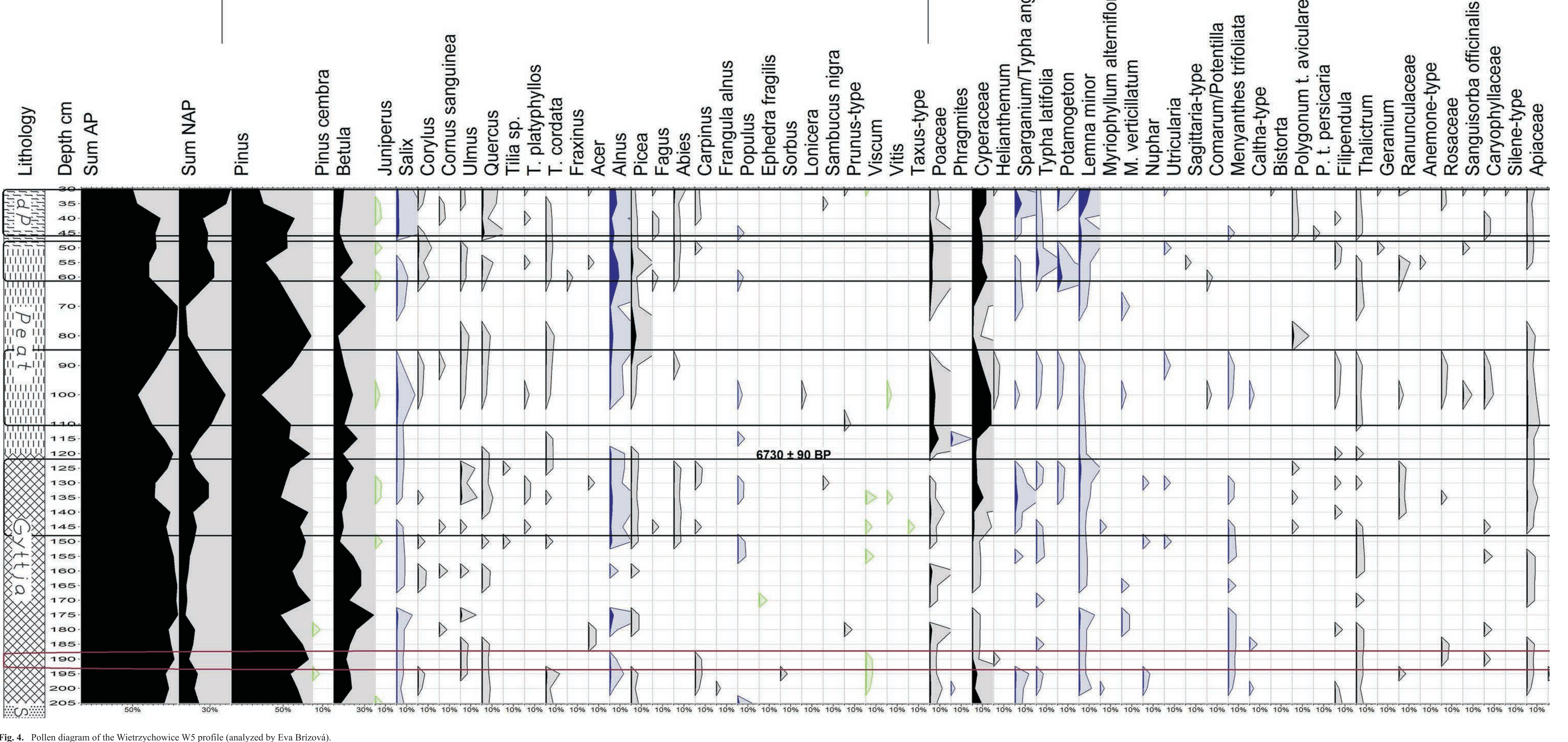




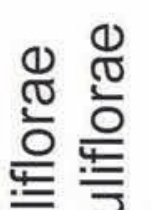

这.

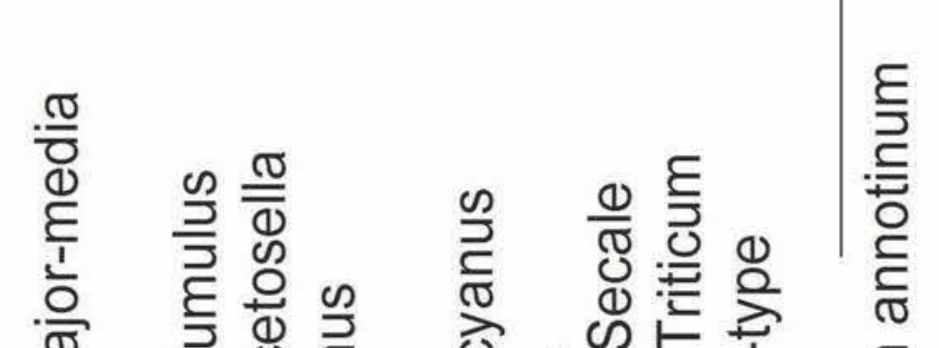

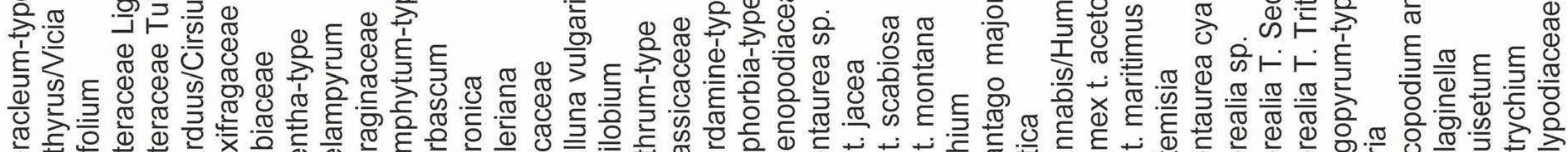

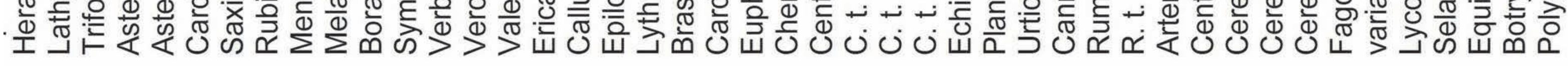

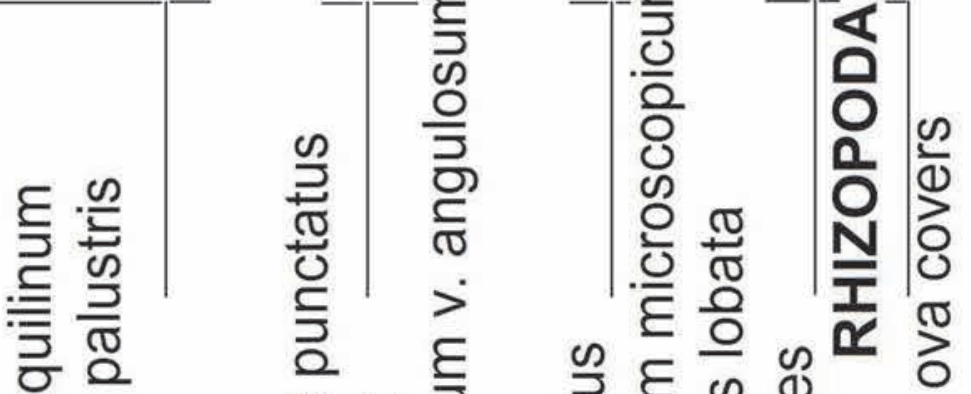
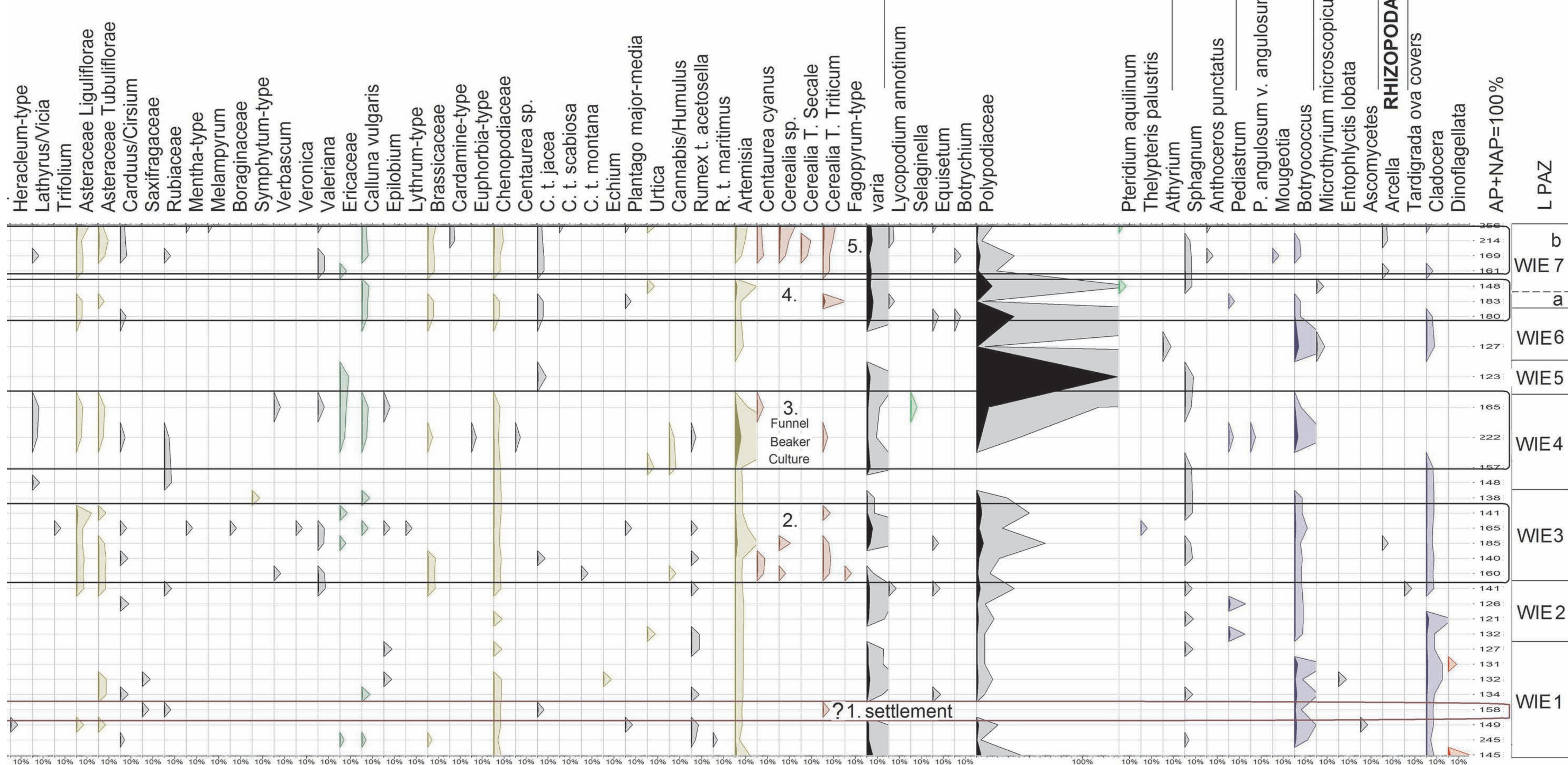
(a) 